\title{
Autódiagnosztikai adatok feldolgozása NI DIAdem programmal
}

\author{
Torma Dávid \\ Mechatronikai Tanszék \\ Debreceni Egyetem, Müszaki Kar \\ Debrecen, Magyarország \\ tormalol@gmail.com
}

\author{
Sarvajcz Kornél \\ Mechatronikai Tanszék \\ Debreceni Egyetem, Müszaki Kar \\ Debrecen, Magyarország \\ sarvajcz@eng.unideb.hu
}

\author{
Dr. habil. Husi Géza \\ Mechatronikai Tanszék \\ Debreceni Egyetem, Müszaki Kar \\ Debrecen, Magyarország \\ husigeza@eng.unideb.hu
}

\begin{abstract}
Absztrakt - Egy olyan autódiagnosztikai feldolgozó szoftvert terveztünk, amely képes automatikusan importálni a szükséges állományokat, létrehozni a megjelenítő felületet, elemezni az információ halmazokat és jelentéseket készíteni előre beállított paraméterek alapján. A szoftver egy komplex autódiagnosztikai rendszer része, amely lehetőséget biztosít a gépjármü diagnosztikai csatlakozóján keresztül adatok kinyerésére, az aktuális pozíció tárolására és az adatok feldolgozására. A program képes videófelvételeket és GPS adatokat is szinkronizáltan hozzárendelni a menetdinamikai adatokhoz, majd animáltan megjeleníteni azokat. A beépített elemző funkciók segítségével az állományok előre definiált feltételeknek megfelelően kerülnek feldolgozásra. A szkriptek segítségével automatikus jelentések készíthetők, amelyek mindig az aktuális igények alapján készülnek el. A választott fejlesztőkörnyezet a National Instruments által fejlesztett NI DIAdem.
\end{abstract}

Kulcsszavak - autódiagnosztika; elemző szoftver; DIAdem; szinkronizálás; megjelenités; National Instruments;

\section{BEVEZETŐ}

A jelenleg elérhető autódiagnosztikai rendszerek vizsgálatára készített eszközök kialakítása, felépítése és árazása jelentős eltéréseket mutat. A legolcsóbb és legegyszerübb termékek néhány ezer forintba, a professzionális márkaszervizekben használtak akár több millió forintba is kerülhetnek. A legtöbb funkció egy középkategóriás eszközzel is elérhetö, de bizonyos jármütípusokhoz elengedhetetlenek a gyári müszerek [1].

Az elérhető eszközöket vizsgálva, arra a következtetésre jutottunk, hogy a legtöbb csak bizonyos megkötésekkel alkalmazható. A legnagyobb problémát a paraméterek megfelelő rögzítése és feldolgozása jelenti. A rögzítés elöre meghatározott jellemzők szerint történik, így a mintavételezés gyakorisága vagy a vizsgálandó paraméterek száma nem változtatható. $\mathrm{Az}$ elemző funkciók az alsó kategóriában egyáltalán nem, a drágábbaknál is csak korlátozva érhetők el.

A NI DIAdem fejlesztő környezetben egy olyan feldolgozó szoftver létrehozása volt a célunk, amellyel az OBD-II (OnBoard Diagnostics) interfészen kinyert adatok megfelelően feldolgozhatók, elemezhetők. A menetdinamikai jellemzők kiegészíthetők GPS adatokkal és videófelvételekkel. A feldolgozó szoftver egy komplex autódiagnosztikai rendszer része, amelyet a kutatócsoport fejleszt [2] [3] [4].

\section{DIAGNOSZTIKAI ADATOK RÖGZÍTÉSE}

A diagnosztikai adatok rögzítéséhez a kutatócsoport által fejlesztett programot alkalmaztuk. A program a LabVIEW fejlesztő környezetben készült, amelyet szintén a National Instruments fejleszt. A támogatottság és kompatibilitás egységes, így a két rendszer párhuzamos használata nem okoz problémát.

A fejlesztett program képes a gépjármüvek diagnosztikai rendszeréből kinyert adatok lementésére. Az állományok rögzítése egy CompactRio Controller (cRIO-9030) segítségével történik. Az eszköz bárki által megvásárolható a National Instruments weboldalán, nem csak professzionális felhasználásra és a nagyvállalatok számára elérhető.

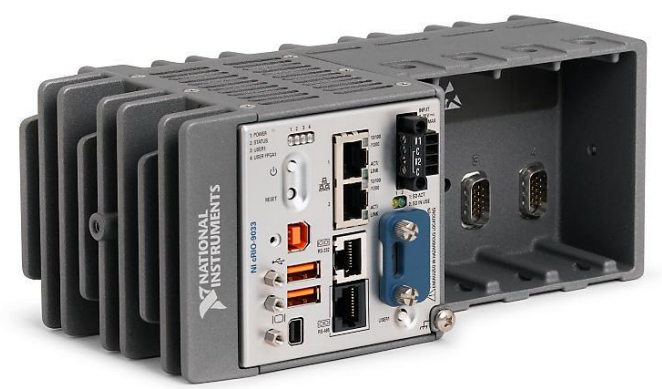

1. ábra Az alkalmazott cRIO-9030

A kontrollerbe illeszthető kiegészítő modul (CAN Interface modul NI-9862) segítségével jön létre a kommunikáció [5] [6]. Ezt az eszközt speciálisan a High Speed CAN rendszerekhez fejlesztették ki, így minden területen alkalmazható, ahol a magas sebességü megoldást használják [7]. 
Az adatok, amelyek rögzítésre kerülnek, nyomon követhetők egy laptop segítségével. Így látható minden pillanatban az aktuális fordulatszám, sebesség és a legtöbb vezetést aktívan befolyásoló tényező. A program több részegységre bontható, amelyek közül a legfontosabb a diagnosztikai adatok megjelenítése.

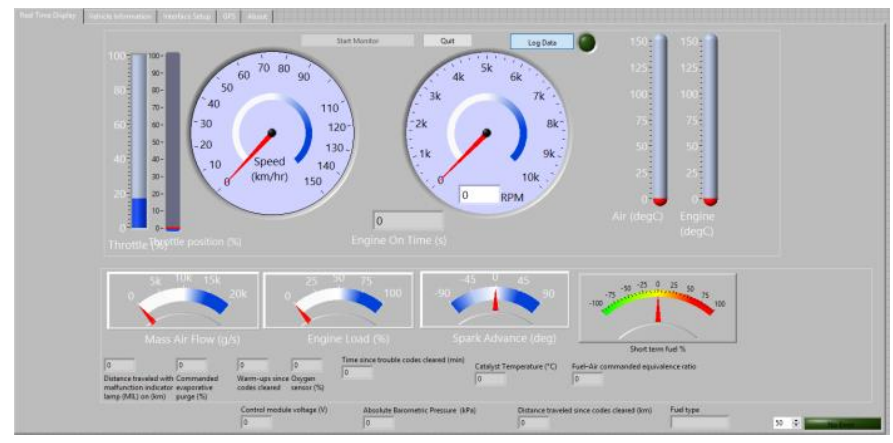

2. ábra Az adatok rögzítéséhez alkalmazott program

A mintavételezés valós körülmények között történt. A menetdinamikai állományok mellett GPS adatok is rögzítésre kerültek. A videófelvétel egy hétköznapi okostelefon segítségével készült.

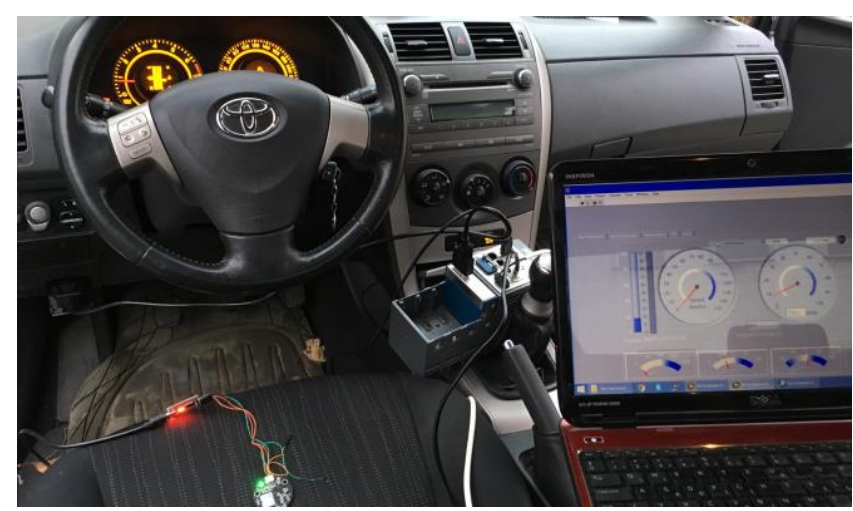

3. ábra Az adatok rögzítése

A szoftver képes az összes szabadon hozzáférhető OBD PID (On-Board diagnostics Parameter IDs) kiolvasására és tárolására. Ezen paraméterek száma bővíthető, de ahhoz speciális gyártói jogosultság szükséges.

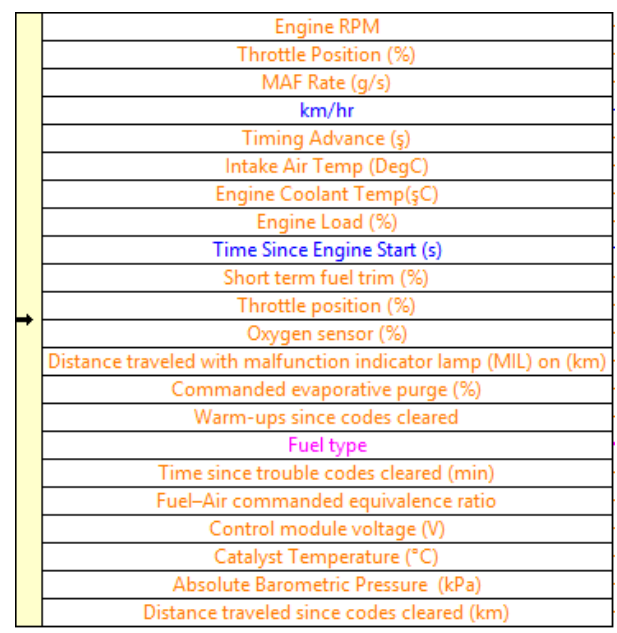

4. ábra A rögzített paraméterek

\section{ADATOK IMPORTÁLÁSA NI DIADEM PROGRAMBA}

A rögzített adatok eltérő fájlokban találhatók. A gépjármü diagnosztikai rendszeréből lementett adatok LVM (LabView Measurement), a helymeghatározáshoz szükséges adatok GPX (GPS eXchange Format) és az elkészített videó AVI (Audio Video Interleave) kiterjesztéssel rendelkezik. Az NI DIAdem programban az eltérő forrásokból származó adatok egy új fájlformátumban tárolódnak, ez a TDM (Technical Data Management) kiterjesztés. Az új formátumot bármikor bővíthetjük más forrásokból származó adatokkal, így utólagosan is szerkeszthető. Az állomány sajátossága a struktúráltság, amely az összevonás után is megmarad. Az egyes elemek szabadon átnevezhetők, szerkeszthetők. Új csoportokat hozhatunk létre, rendezhetjük és szétválaszthatjuk állományainkat. Az adatok a Data Portal felületen érhetők el, a beállított elrendezésnek megfelelően.

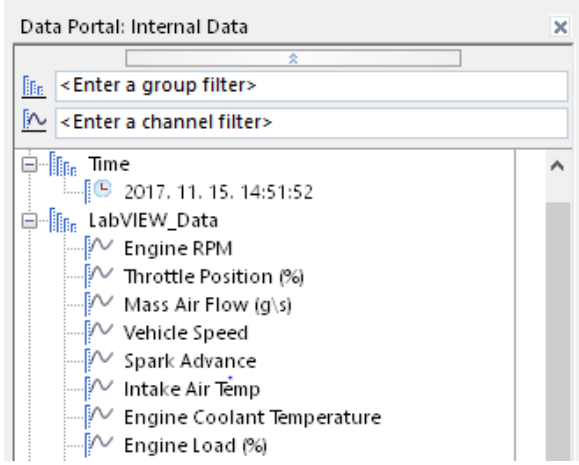

5. ábra Data Portal felület

Az adatok megjelenítése több területen is történhet, amelyek száma és mérete módosítható. Olyan felület hozható létre, amely az aktuális igényekhez a legjobban megfelel. 


\begin{tabular}{|c|c|c|}
\hline Display Type & $>$ & 2D Axis System \\
\hline \multirow{3}{*}{$\begin{array}{l}\text { New Area } \\
\text { Delete Area }\end{array}$} & \multirow[t]{3}{*}{$>$} & Channel Table \\
\hline & & Textbox \\
\hline & & Video \\
\hline Display Coordinates & & Image \\
\hline Switch Screen Mode & & 3D Model \\
\hline End Interaction & & Contour \\
\hline Help & & \\
\hline & & $\checkmark$ Empty \\
\hline
\end{tabular}

6. ábra Választható terület típusok

A maximális egy időben megjeleníthető eltérő modulok száma nem limitált, de az átláthatóságukat a megjelenítő felület nagysága korlátozza. Nagy mennyiségü adatot célszerü eltérő oldalakon megjeleníteni. Az idő szerinti szinkronizálás csak az adott oldalra vonatkozik, az eltérő lapokon felépített felületek szinkronizált futtatása nem lehetséges. A megjelenítő felületek kiterjesztése TDV (Technical Data View), ami az NI DIAdem saját fejlesztésủ formátuma.

\section{IV. ÁtTEKINTŐ FELÜLET ELKÉSZÍTÉSE}

Az adatok feldolgozásához egy áttekintő felületet hoztunk létre. Ezen megtalálható a sebesség $[\mathrm{Km} / \mathrm{h}]$ és a percenkénti fordulatszáma [RPM] a motornak. Ez egészül ki egy videó felvétellel és egy térképpel, amelyen az aktuális pozíció látható. A sebesség és fordulatszám értékeket grafikonokon jelenítettük meg az idő függvényében. Egy grafikonon egyszerre több érték is megjeleníthető, a vonalvastagság és a szín megváltoztatható. Kiemelhetünk részleteket, speciális pontokat. A mintavételezés $[10 \mathrm{~ms}]$ volt, így az adatok felhasználhatók diagnosztikai célokra.

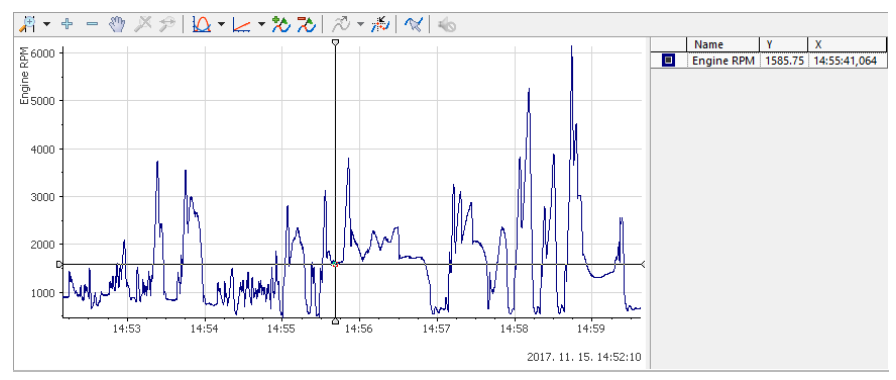

7. ábra A motor percenkénti fordulatszáma

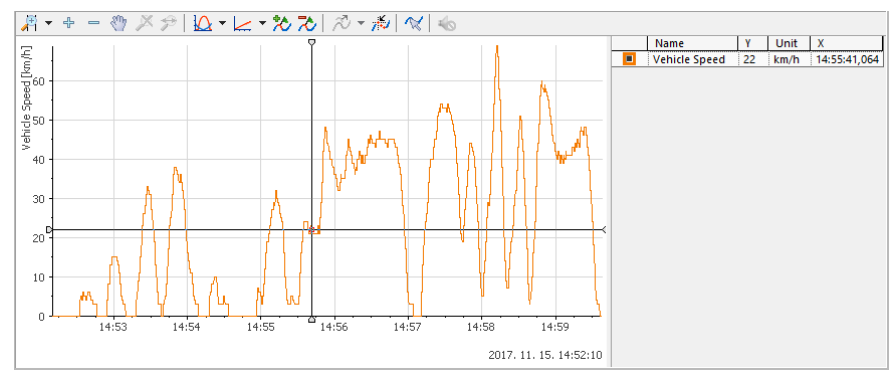

8. ábra A gépjármü pillanatnyi sebessége

Az NI DIAdem kizárólag AVI és MPEG formátummal rendelkező videók megjelenítését támogatja. A felvétel amit használtunk AVI kiterjesztésü, 720x576 pixel felbontású. Nagy felbontás nem ajánlott, a program nehezen kezeli. A szinkronizáláshoz a videó indítási idejének a 0000 . év 01. hónap 01. nap 00:00:00-tól eltelt időt kell megadni másodpercekben. Ezen érték kiszámítható a beépített számológép segítségével.

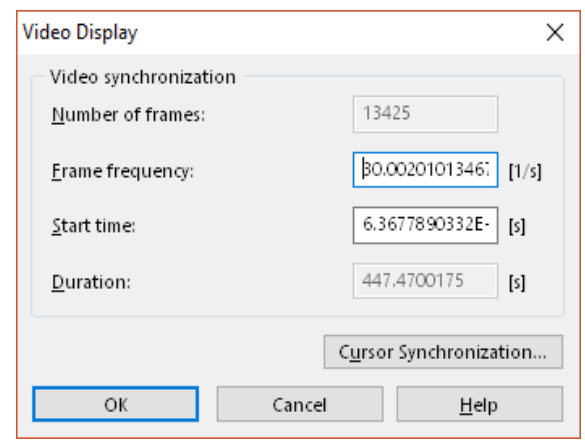

9. ábra A videó részleteinek beállítása

A GPS adatok az idő függvényében jelennek meg, a megtett útvonal kirajzolódik a térképen. Az NI DIAdem az OpenSreetMaps és Microsoft MapPoint ingyenes térképein képes megjeleníteni adatokat. A program elkészítése során a Microsoft megoldása nem volt elérhető, így az OpenSreetMaps térképét használtuk.

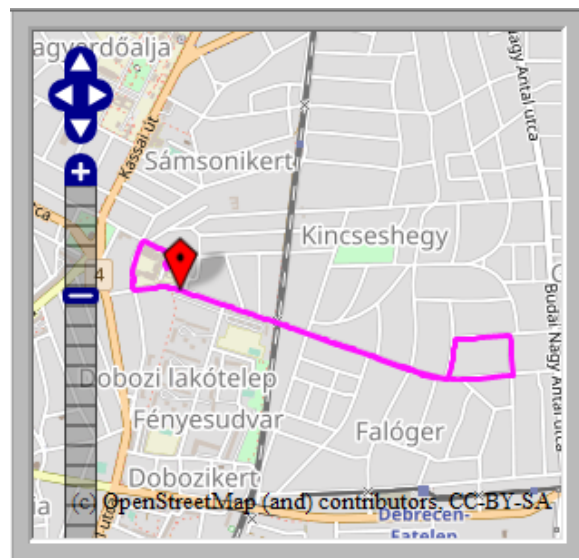

10. ábra A GPS adatok megjelenítése

A program számos elemző funkcióval rendelkezik. Az egyik ilyen funkció a csúcspontok megtalálása. Ezzel a módszerrel egyszerủen megtalálhatók a maximális értékek, amelyeket ezt követően a grafikonokon is jelölhetünk.

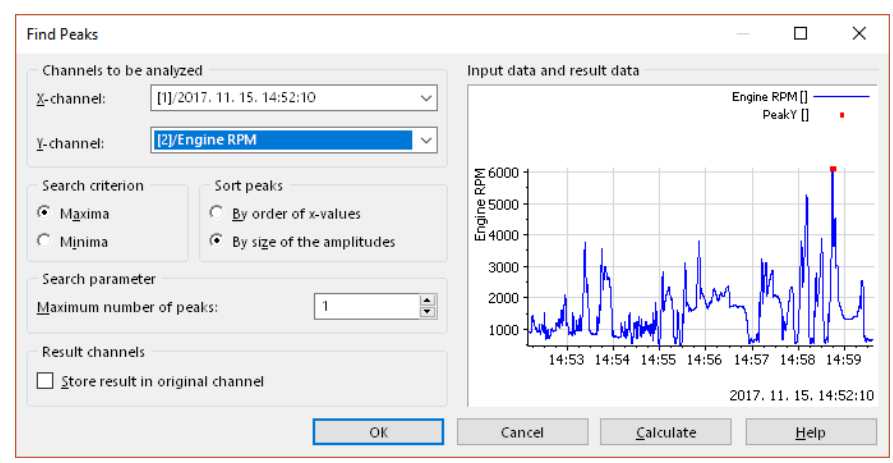

11. ábra Csúcspontok automatikus jelölése 
Az NI DIAdemben lehetőségünk van az összes adatot az idő függvényében szinkronizáltan, egyszerre megjeleníteni. Elöre beállított sebesség alapján folyamatosan frissülnek az adatok, a kurzorok a grafikonok görbéit követik. A térkép és a menetdinamikai adatoknak azonos szinkronizációs alapot kell biztosítani, csak így lesznek tökéletes összhangban.

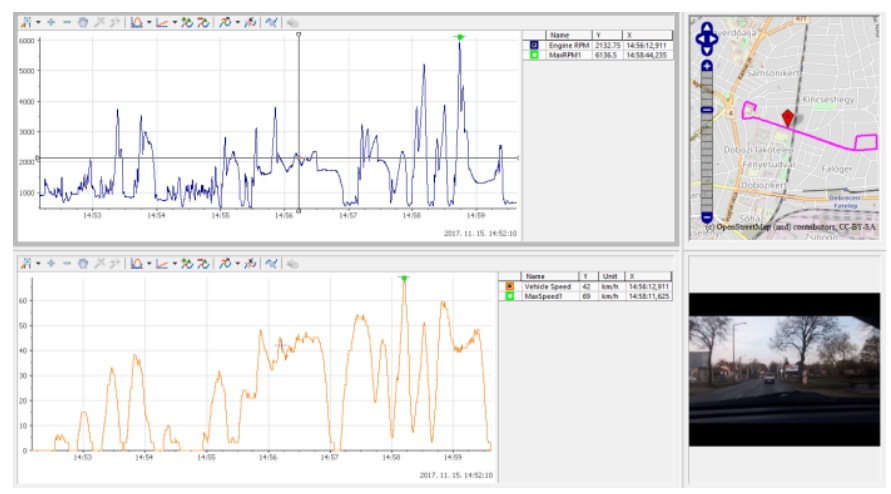

12. ábra Az elkészült áttekintő felület

A lejátszás sebessége beállítható, alaphelyzetben másodpercenként frissülnek az értékek. Lehetőségünk van manuálisan az ikonok, vagy a grafikonok felületén az egér segítségével a kívánt időponthoz állítani lejátszást.

\section{A MOTOR KEVERÉKILLESZTÉSÉNEK ELEMZÉSE}

A motor keverékillesztése határozza meg, hogy az égéstérbe milyen arányban kell üzemanyagot juttatni. A motornak azonos teljesítmény leadására kell képesnek lennie eltérő körülmények között is. A reggeli hidegindítás után, tartós autópálya tempónál vagy emelkedőn történő közlekedésnél, eltérő üzemanyag befecskendezés szükséges. Ezt az ECU (Engine Control Unit) szabályozza, amely a különböző szenzorokból érkező jeleket feldolgozva, létrehozza az illesztés arányát.

Az vezérlőegység a STFT (Short Term Fuel Trim) arányát az oxigénszenzor értéke alapján állítja be. Ha az STFT értéke +/- 10\% között található, akkor hibamentes müködésröl beszélhetünk. Abban az esetben, ha az érték eléri a +/- 25\%-ot, a MIL lámpa kigyullad, a hibás értékek tárolódnak a diagnosztikai rendszerben.

Az STFU és az oxigén szenzorból érkező jeleket összehasonlítva, észrevehető az egyezés. Ennek oka, hogy a kipufogórendszerben található gázok oxigéntartalma alapján történik a keverékillesztés. Az értékeket alaposabban vizsgálva azonban megfigyelhető, hogy eltérések mutatkoznak. Ez az aktuális és kalkulált értékek közötti eltérés.

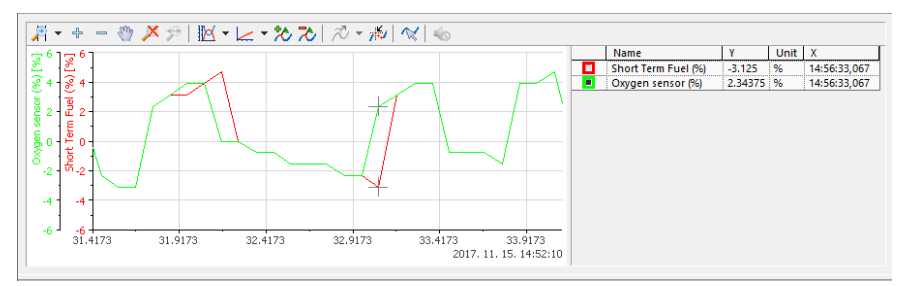

13. ábra Az STFU és az oxigénszenzor érékének összehasonliása
Az értékek százalékosak, így ezeket kivonva egymásból, megkapjuk az abszolút eltérést. Ezen információkat az ECU fejlesztéséhez, illetve a keverékillesztés arányának optimalizáláshoz használhatjuk fel. Az értékek kivonását a beépített elemző függvények segítségével valósítottuk meg.

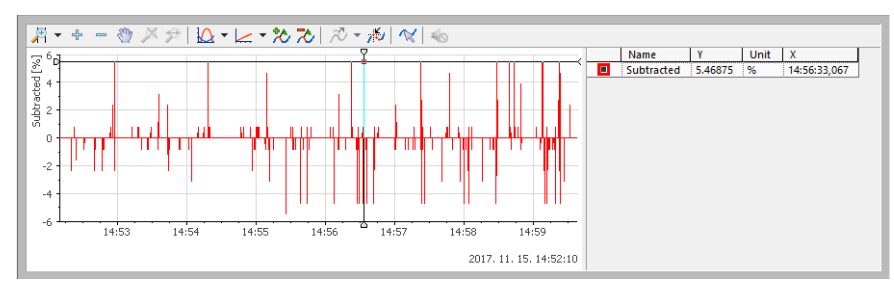

14. ábra Az STFU és az oxigénszenzor értékének különbsége

Így minden időpillanatban látható a két érték abszolút különbsége. Az értékeket lehetőségünk van szinkronizáltan, a többi adattal párhuzamosan megjeleníteni.

\section{A SEBESSÉG ÉS FORDULATSZÁM ÉRTÉKÉNEK VIZSGÁLATA}

Az jármü sebességének és a motor fordulatszámának vizsgálata megkerülhetetlen, ha a fogyasztást szeretnénk optimalizálni. Általános használat mellett elmondható, hogy a fordulatszám 3500 feletti értéke magasnak tekinthető. A magas fordulatszám a fogyasztás növekedését okozza. Az NI DIAdem beépített elemző funkciójával, az adott érték feletti fordulatszám egyszerüen megjeleníthető.

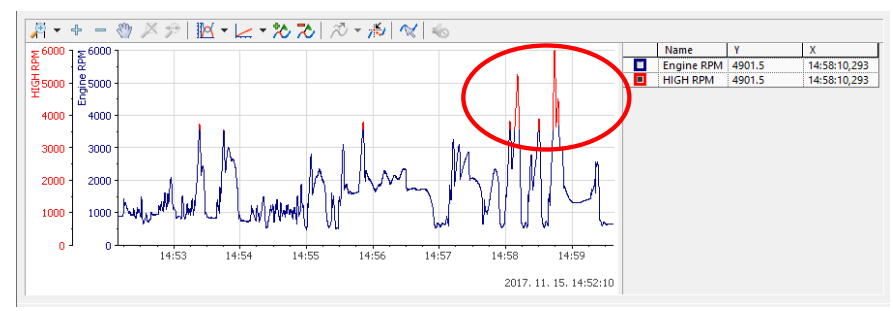

15. ábra A túl magas fordulatszám ábrázolása

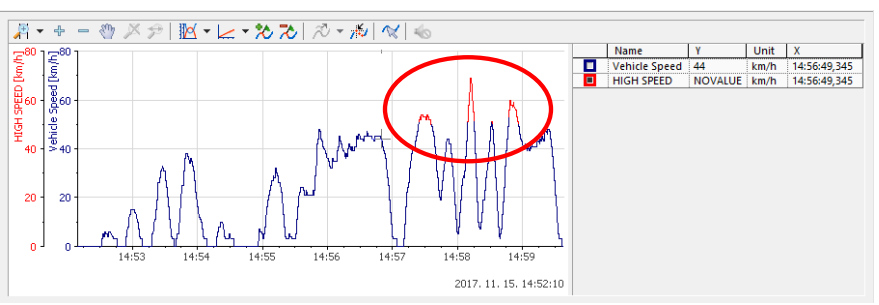

16. ábra A túl magas sebesség ábrázolása

A magasabb sebesség az üzemanyagfogyasztás növekedését okozza. Ezen kívül, a megengedett sebesség átlépése nagyon veszélyes. Az adatok utólagos elemzésével láthatóvá válnak azon területek, ahol a megengedett sebességhatárokat átlépve közlekedtünk. A vizsgálatokat a program automatikusan végzi el, az elöre beállított küszöbértékek figyelembevételével.

A sebesség értékeket a beépített függvények segítségével hisztogrammokon is ábrázolhatjuk. Így látható a bizonyos értékek gyakoriságának megoszlása. A leggyakoribb tartomány a 0-10 [Km/h], ami a jelentős délutáni forgalom 
következménye. Ezt követi a 40-50 [Km/h], amely a városi közlekedés megengedett tartománya. Az értékek vizsgálatával a városban közlekedő jármüvek átlagos sebességére lehet következtetni. Eltérő időtartományban történő mintavételezéssel, a forgalom változása vizsgálható a kritikus időtartományokban.

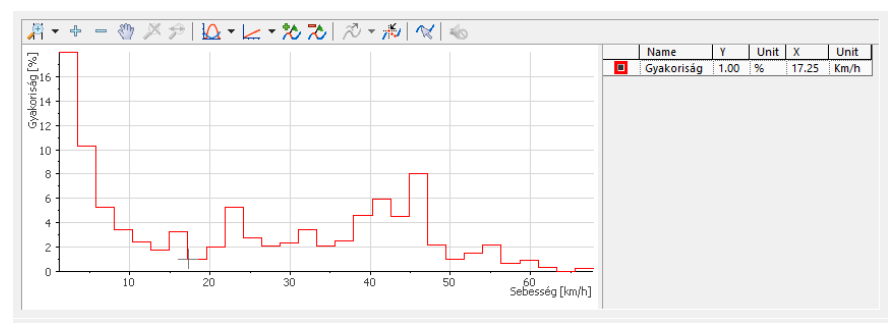

17. ábra A sebességértékek gyakoriságának eloszlása

\section{A GENERÁTOR TELJESÍTMÉNYÉNEK VIZSGÁLATA}

A gépjármü generátorának megfelelő müködésére az akkumulátor feszültségállapotából következtethetünk. Így lehetőségünk van a generátor müködésének tanulmányozására, speciális eszközök nélkül is. Az OBD-II interfészen keresztül hozzáférhetünk az ECU feszültségállapotához. Az ECU és a gépjármű akkumulátora közötti feszültségkülönbség minimális, így ezen érték is alkalmazható a generátor vizsgálatára.

A generátorok átlagosan 13,5-13,6 [V] töltőfeszültséggel rendelkeznek, ha a motor alapjáraton üzemel. Az alapjárat értéke, egy hétköznapi 4 hengeres benzines belsőégésü motorral rendelkező személygépjármüben 700-800 RPM. A maximálisan megengedhető töltőfeszültség 14,4 [V], amely felett veszélyes buborékképződés alakulhat ki. Az értékek generátor- és gépjármü típusonként eltérhetnek.

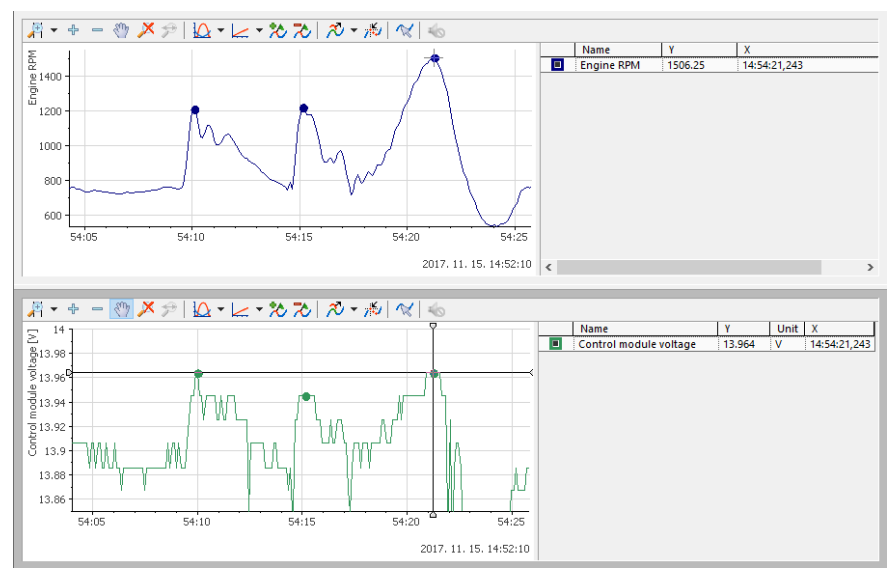

18. ábra A fordulatszám és a töltőfeszültség közötti kapcsolat

A 18. ábrán jól látható a töltőfeszültség és a motor fordulatszámának összefüggése. A két érték jelleggörbéje nagyon hasonló, így a generátor megfelelő müködésére következtethetünk. A mért adatok alapján, a legalacsonyabb fordulatszámnál 13,242 [V], a legmagasabbnál 13,964 [V] töltöfeszültség keletkezett. Az értékek közötti eltérés 5,17 [\%], amely egy megfelelően müködő generátorra enged következtetni.

\section{MENETDINAMIKAI ÉS HÖMÉRSÉKLET ÉRTÉKEK ELEMZÉSE}

A károsanyag kibocsájtás csökkentésében hatalmas szerepe van a katalizátoroknak. Ez a kipufogóban található eszköz, a gázok károsanyag tartalmát minimalizálja. A három gázkomponensre ható katalizátorok mind a nitrogén-oxidok, a szénhidrogének és a szén-monoxid szintjét jelentősen csökkentik. Ezen eszközökben elhelyezett lambda-szonda méri az oxigénszintet, amely alapján az ECU a motorba juttatott üzemanyag-levegő arányát meghatározza.

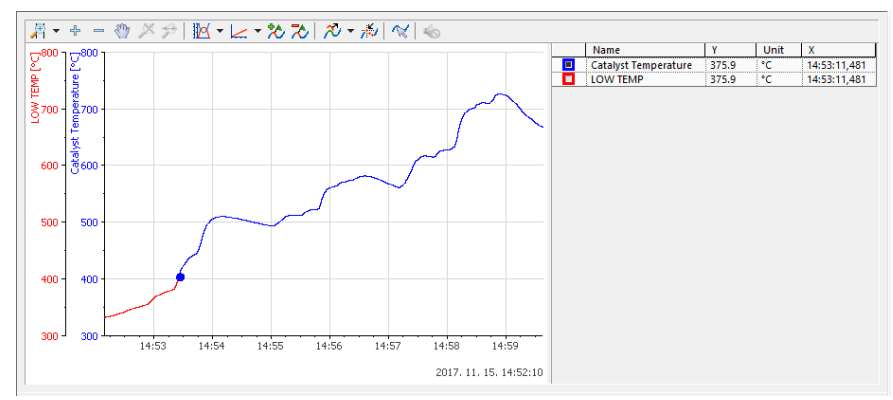

19. ábra A katalizátor hőmérsékletváltozása

A megfelelő müködéshez $400\left[{ }^{\circ} \mathrm{C}\right]$ feletti hőmérséklet szükséges. Alacsonyabb értéknél a katalizátor hatásfoka nem megfelelő, a károsanyag kibocsájtás magas. Az NI DIAdem elemző funkciójával a 19. ábrán megjelenítettem azon időtartományt, ahol a katalizátor hőmérséklete még nem volt elfogadható. A melegedés idejének gyorsításával, a levegőbe juttatott károsanyag csökkenthető.

\section{SZKRIPT KÉSZÍTÉS NI DIADEM SEGÍTSÉGÉVEL}

Az NI DIAdem lehetőséget biztosít szkriptek készítéséhez is. A szkriptek olyan rövid programok, amelyek általában egy adott alkalmazás vagy müködési környezet vezérlését teszik lehetővé elemi utasítások segítségével. Így lehetőségünk van az adatokat betölteni, elemzéseket készíteni, megjelenítő felületeket szinkronizálni vagy a jelentéseket létrehozni egyetlen programkód lefuttatásával. Egy megfelelően elkészített szkript segítségével az adatok elemzésére fordított időt jelentősen csökkenthetjük. Az NI DIAdemben alkalmazott szkript nyelvezete hasonló a C programozási nyelvhez, így megértése nem okozott problémát. A szkirpt VBS (Visual Basic Script) kiterjesztéssel rendelkezik, ami a DIAdem-ben alkalmazott programnyelv. Bármilyen szövegszerkesztővel megnyitható és módosítható.

A programmal automatikusan is készíthetünk szkripteket. Ehhez egy úgynevezett „Start Recording” funkciót kell aktiválni. Igy nem szükséges a szkriptek manuális megírása, hanem a program automatikusan elkészíti azokat. Mindössze használnunk kell a programot, a háttérbe futó algoritmus pedig elkészíti a parancsok sorozatát.

Az általunk készített szkript futtatását követően a nyers adatok importálása megtörténik, majd a kiválasztott elemző funkciók végrehajtódnak. A választott elemzések a fordulatszám adott értéknél történő szétválasztása, illetve a sebesség értékek hisztogrammon történő ábrázolása. A szkript sajátossága, hogy az értéket, ahol a szétválasztás történik a 
futtatás után közvetlenül megadhatjuk. Ezen kívül, lehetőségünk van a hisztorgrammon megjelenített osztályok számának megadására is. Így mindig az aktuális igényekhez megfelelő adatok jelennek meg. Ehhez a háttérben elkészült programkód kiegészítése volt szükséges. A paraméterek megadása egy vizuális felületen történik, így nem szükséges a programkód manuális átírása.

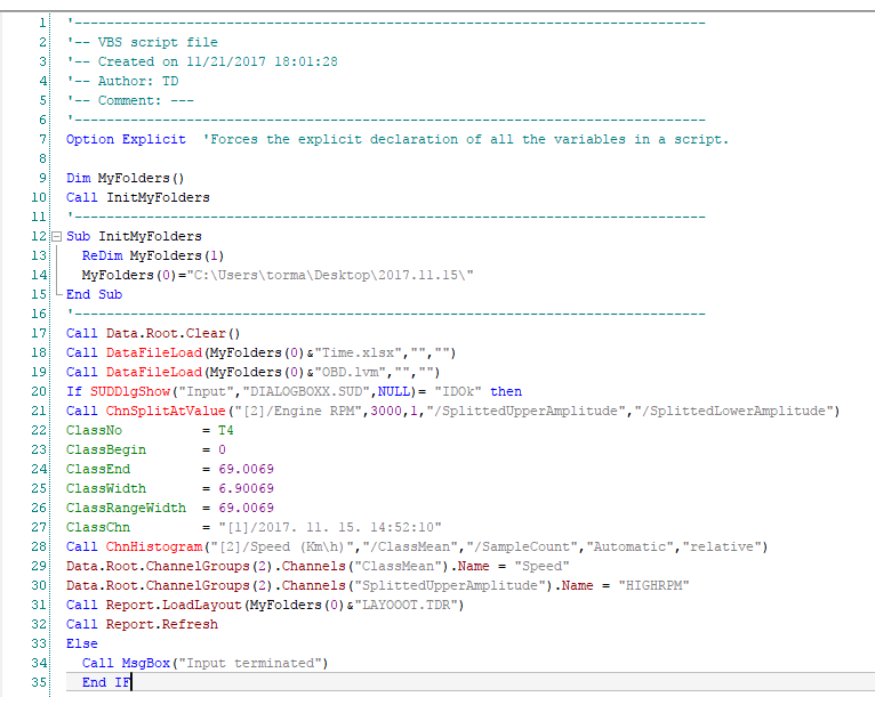

20. ábra Az elkészült szkript

Az paraméterek megadását követően, a beírt jellemzőknek megfelelően elkészül a jelentés. A jelentés tartalmazza a megadott értékek szerint végrehajtott elemzést, a nevet és Neptun kódot. Az elemzés eredményei grafikonokon kerülnek ábrázolásra, a személyre utaló információk az alsó sávban kaptak helyet. Az elkészült jelentés a 21. ábrán látható.

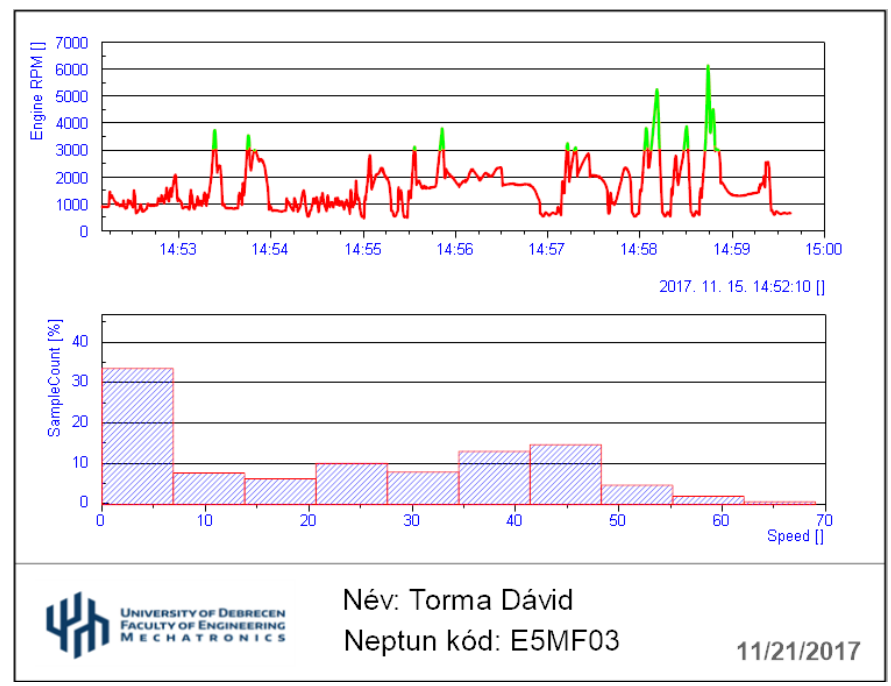

21. ábra A szkript által készített jelentés

\section{AZ ELEMZŐ SZOFTVER FELÉPÍTÉSE}

Az elkészített felületek között az alsó sávban válthatunk. A területek szétválasztása az átláthatóságot szolgálja. Így mindig csak az érintett információk kerülnek feldolgozásra. A területek sorrendje és neve változtatható. A felületek megjelenítése teljes képernyőn is történhet, ehhez csak a nézet átváltása szükséges.

A bal oldali sávban a különböző részegységek között válthatunk. Itt található az adatok betöltése, a megjelenítő felület, az elemzések, a jelentés és szkript készítés. A felső sávban az aktuális részegységhez kapcsolódó almenü látható. A megjelenítő felületek esetében, itt található a szinkronizált lejátszás irányítása. Ezen kívül, itt találhatók az általános menüpontok, mint a mentés vagy a betöltés.

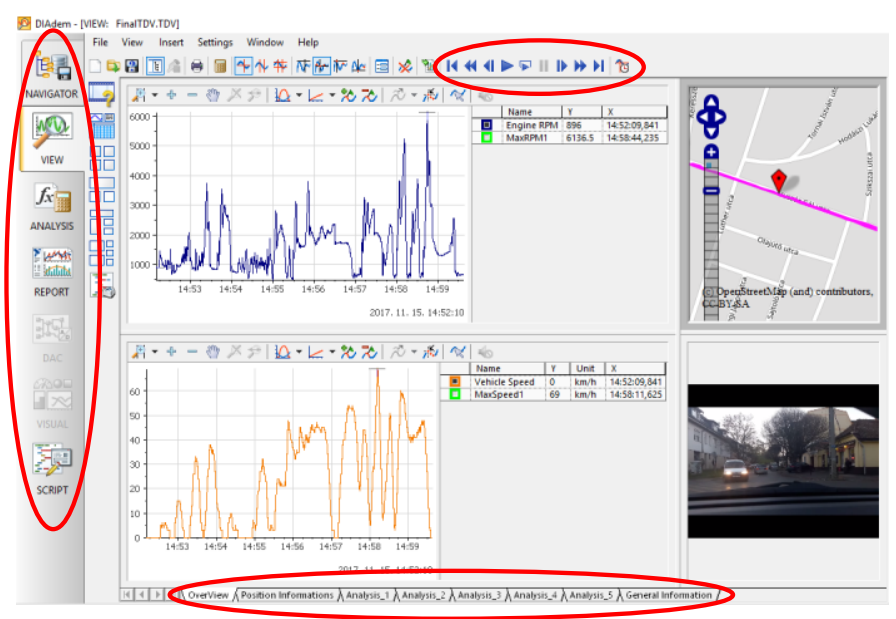

22. ábra Az elemző szoftver felépítése

\section{A PROGRAM FELHASZNÁLÁSI ÉS FEJLESZTÉSI LEHETŐSÉGEI}

Az elemzések felhasználhatók vezetési stílusok meghatározásához, útvonalak vizsgálatához, fogyasztás optimalizáláshoz és olyan rendszerek fejlesztéséhez, amelyekhez az autók menetdinamikai adatai szükségesek. A program hatalmas elönye a versenytársakhoz képest, hogy bővíthető és átalakítható.

\section{XII. ÖSSZEFOGLALÓ}

Az elkészített elemző szoftver képes automatikusan importálni a szükséges állományokat, létrehozni a megjelenítő felületet, elemezni az információ halmazokat és jelentéseket készíteni elöre beállított paraméterek alapján. A megjelenítő felületeken az adatok szinkronizált lejátszása biztosított. A beépített elemző funkciók segítségével az adatok megfelelö feldolgozása is megvalósul. Az automatikus jelentések hozzájárulnak a hatékony munkavégzéshez. Így egy olyan komplex program jött létre, amely jelentősen megkönnyíti a mérnökök és a tudósok munkáját. Az NI DIAdem használata erősen ajánlott, minden területen, ahol nagy mennyiségü és eltérő struktúrájú adat feldolgozása szükséges azonos időalapon. A program egyszerüen használható, nem igényel speciális programozási ismereteket. Moduláris felépítésü, egyszerüen átalakítható és bővíthető.

\section{KÖSZÖNETNYÍLVÁNÍTÁS}

A publikáció/prezentáció/poszter elkészítését az EFOP3.6.1-16-2016-00022 számú projekt támogatta. A projekt az 
Európai Unió támogatásával, az Európai Szociális Alap társfinanszírozásával valósult meg.

\section{HIVATKOZÁSOK}

[1] Dr. Lakatos István, Fedélzeti diagnosztika (OBD, EOBD), A követelménymodul száma: 0619-06

[2] Dr. Fodor Dénes, „Autóipari kommunikációs protokollok - a CAN" (Veszprém, 2012)

[3] ETSCHBERGER, K. (2001). Controller Area Network. IXXAT Press, Weingarten

[4] FARSI, M. and BARBOSA, M. (2000). CANopen Implementation: applications to industrial networks. Research Studies Press Ltd., Baldock
[5] ISO-WD 11898-2 (1999). Road vehicles - Controller area network (CAN) - Part 2: High speed medium access unit

[6] ISO-WD 11898-3 (1999). Road vehicles - Controller area network (CAN) - Part 3: Low speed medium access unit

[7] LAWRENCE, W. (1997). CAN System Engineering From Theory to Practical Applications. Springer-Verlag, New York 